\title{
CHANGE OF HYDRATION PARAMETERS IN MODERATE ALTITUDE: MEASUREMENTS IN HEALTHY VOLUNTEERS BY MEANS OF BIOELECTRIC IMPEDANCE ANALYSIS
}

\author{
Christoph Raschka ${ }^{1}$, Horst J. Koch ${ }^{2}$, \\ JOHANNES KÄSEBIETER ${ }^{3}$ \\ ${ }^{1}$ Institute of Sports Sciences, Julius-Maximilians-University, Würzburg, Germany \\ ${ }^{2}$ Heinrich-Braun-Klinikum, Zwickau, Germany \\ ${ }^{3}$ Doctor of Veterinary Medicine, Wedemark, Germany
}

\begin{abstract}
During residence in high mountain regions, the human water hydration status changes and, from the height of approximately $3000 \mathrm{~m}$ above sea level, is associated with the risk of mountain sickness. The present investigation should assess this phenomenon in moderate height (1300-2300 m above sea level) after a residence time of approximately one week by means of bioelectric impedance analysis (BIA). 50 volunteers, attendees of a sports medicine congress (33 men, 17 women), agreed to enter the study. All participants underwent BIA measurements initially and after one week. Apart from the basic characteristics - resistance (resistor, R) and capacitor resistor (reactance, $\mathrm{Xc}$ ) - derived characteristics, such as total body water (TBW), body cell mass (BCM) and extra-cellular mass (ECM) were of interest. Significant changes after the stay in moderate altitude were not verified. As resistance decreased in both men and women, extracellular hydration was probably stimulated. Altogether, the study shows that an approximately one-week stay had no substantial influence on the BIA parameters in moderate altitude. In this regard, additional investigations in high altitudes or studies with longer duration of stay should be encouraged.
\end{abstract}

Keywords: bioelectric impedance analysis; mountain medicine; hydration; healthy volunteers 


\section{INTRODUCTION}

Bioimpedance analysis (BIA) has established itself as a non-invasive method in the health, nutrition and fitness area and especially in sports medicine [17, $18,25]$. Even if there are critical assessments of the methodology, especially with regard to the fat and fluid balance in sports medicine [11,27], the method and analogous methods - impedance vector analysis (IVA) - are increasingly being used internationally and are regularly restandardized $[3,21,24]$. In one study, the BIA proved to be inferior to the clinical scores regarding the prognosis in dialysis patients, whereby the authors discuss an improved evaluation using impedance vector analysis [6]. As a prognostic parameter, the phase angle seems to be sufficiently valid for clinical practice in order to recognize risk patients with consuming diseases at an early stage and is increasingly used internationally and regularly restandardized [23].

So far, there are only a few studies that have used the BIA as a method in mountain and expedition medicine.

The present study aimed to develop a data basis and answer the question whether the water balance of healthy test subjects changes at a moderate altitude (1300-2300 $\mathrm{m}$ above sea level) and provide information as to whether the method could be suitable for the early detection of altitude sickness.

The suitability has been demonstrated on expeditions in high mountains at $6000 \mathrm{~m}$ above sea level [5].

\section{METHODOLOGY}

\section{Subjects}

50 subjects (aged $28-57$ years) were included in the study. All participants gave their informed consent. 33 men and 17 women were included.

The detailed demographic and anthropometric data are summarized in Table 1.

During the study, the subjects did not change their eating or smoking habits. A specific number of subjects was not planned in the absence of comparative data. The number of 50 subjects was considered sufficient to generate statistical parameters. 
Table 1. Demographic and anthropometric data of the included subjects

\begin{tabular}{lcccc}
\hline $\begin{array}{l}\text { Males } \\
\mathrm{n}=33\end{array}$ & $\begin{array}{c}\text { age } \\
{[\text { years }]}\end{array}$ & $\begin{array}{c}\text { weight } \\
{[\mathrm{kg}]}\end{array}$ & $\begin{array}{c}\text { height } \\
{[\mathrm{m}]}\end{array}$ & $\begin{array}{c}\text { BMI } \\
{\left[\mathrm{kg} / \mathrm{m}^{2}\right]}\end{array}$ \\
\hline Average & 46.6 & 84.1 & 1.81 & 20.7 \\
\hline Median & 51.0 & 83.0 & 1.80 & 25.7 \\
\hline SD & 11.49 & 10.8 & 0.053 & 2.94 \\
\hline Range & 45.0 & 48.0 & 0.23 & 15.2 \\
\hline $\begin{array}{l}\text { Females } \\
\mathbf{n}=17\end{array}$ & & & & \\
\hline Average & 46.3 & 66.0 & 1.70 & 22.67 \\
\hline Median & 49.0 & 65.9 & 1.71 & 22.0 \\
\hline SD & 7.35 & 9.78 & 0.08 & 2.63 \\
\hline Range & 28.0 & 31.9 & 0.31 & 9.2 \\
\hline
\end{tabular}

\section{Physical and physiological basics of phase-sensitive bioimpedance analysis}

In the electrical circuit, a distinction is made between active and reactive resistors (capacitor or coil). In the case of pure active resistance (resistance), the basic principles of Ohm's law apply without a phase difference (phase angle) between current and voltage being observed.

Applied to physiology, the pure resistance R mainly corresponds to the water content of the body $[1,8,19]$.

With - usually sinusoidal - alternating currents, the cellular parts of the body mass (membrane; body cell mass - BCM) act in the sense of a capacitor, so that the capacitive resistance (reactance $\mathrm{Xc}$ ) depends directly on the applied frequency $\left(\mathrm{Xc}=1 / 2^{\star} \pi^{\star} \mathrm{f}^{\star} \mathrm{C}\right.$ ) and the capacity $\mathrm{C}$ (cells). Reactance is normally $10-12 \%$ of the effective resistance $\mathrm{R}$ of a tissue. Capacitive resistance $\mathrm{Xc}$ is a measure of the intactness of the cells acting as capacitors. In the case of pure resistance, current and voltage rise and fall simultaneously. If alternating currents pass through an ideal capacitor - no real current passage, the current I leads the voltage $\mathrm{U}$ by a quarter period $\left(90^{\circ}\right.$ or $\pi / 2=\Delta \varphi ; 360^{\circ}=2 \pi=1$ period $\mathrm{T}$ ).

The phase angle $\varphi$ depends on the body cell mass (BCM) and the cell integrity. Normally healthy test subjects reach normal values of $5-7.5^{\circ}$, in ideal physical condition also up to $9^{\circ}$. Specifically, the phase angle can be measured using the relationship $\tan \varphi=1 / 2{ }^{*} \pi^{*} \mathrm{f}^{\star} \mathrm{C}$ or $\varphi=\mathrm{Xc} / \mathrm{R}{ }^{*} 180 / \pi[1,8,14]$.

First of all, it makes sense to look at the raw data $(\mathrm{R}, \mathrm{Xc})$. The nutritional index EI is defined by the simple relationship EI $=100 / 0.1{ }^{\star} \mathrm{R}^{\star} \mathrm{Xc}$. The phase 
angle can also be determined directly [12]. The bioimpedance parameters we are familiar with must be standardized using complex regression equations (See overview [15]).

Total body water (TBW) can be estimated on a gender-specific basis using the resistance, body weight and height. Statements about intracellular and extracellular body water (ICW, ECW) are also possible. Complex regression equations including a factor for gender provide the free fat mass (FFM) and the fat mass (FM). FM $=$ KG-FFM and TBW $=0.732 *$ FFM. The reactance (Xc) allows an estimation of the body cell mass (BCM) or the extracellular mass (ECM) using analogous equations. The ECM / BCM index can be interpreted as an indication of a deterioration in nutritional status (Tables and guidelines, online, [20]). The measurements of the bioimpedance analysis have proven to be valid [4].

\section{Design of the study}

All the subjects underwent two sequential measurement series (period 1: 50-305 m above sea level; period 2: 1300 to $2300 \mathrm{~m}$ above sea level). In all the subjects, the following measured values were determined using BIA within 48 hours of arrival in St. Anton: R, Xc, the phase angle, TBW, BCM and ECM. In addition, the anthropometric data (body weight, height and body mass index) were determined. Subsequently, the test subjects only stayed in the Arlberg ski area, and the measurement was repeated 5 to 7 days later. Complaints (headache, dizziness) were also checked after the second measurement. All the measurements were carried out by an experienced tester using a phasesensitive multifrequency device at $50 \mathrm{kHz}$ under standardized conditions between 6 p.m. and 8 p.m. in a lying position (Nutriguard MS) [13].

\section{Statistical evaluation}

All the data were evaluated descriptively (mean, SD, SEM, median, range) and presented in a suitable form - graphically or in tabular form. Depending on the data structure, categorized histograms or box plots were used, separated by period and gender. Since the distributions varied considerably, non-parametric multivariate comparisons were carried out using the Kruskal-Wallis test or, in the case of bivariate comparisons, the Mann-Whitney test (unconnected sample) or the Wilcoxon test (connected sample). A p-value less than 0.05 was considered significant. As this is an orientation study, no case number planning was carried out. A case number of 50 (2-period study) was considered sufficient $[22,28,29]$. 
Commercial and licensed statistical software was used for the calculations: NCSS 2007 Statistical Analysis and Graphics, Version 07.1.21, NCSS LLC, Kaysville, Utah, USA, 2007, Statistica Version 6, 2000, Statsoft, Tulsa, OK, USA, 2000 and Systat Version 13, Systat Software Inc., Chicago, Il, USA, 2009.

\section{RESULTS}

The most important results are summarized in Table 2. There were no statistical differences between periods 1 and 2 (Wilcoxon test). The differences between men and women are known and correspond to physiological expectations.

At best, slight tendencies can be derived in relation to the period (Table 2). The ECM/BCM index (Fig. 1) tends to be slightly lower, which corresponds to a relative increase in cell mass. Resistance R-50, mainly determined by increased body water, tends to low values, but this does not affect TBW (Fig. 2). Reactance Xc-50 also decreases minimally, which indicates discretely reduced cell integrity. In contrast, the phase angle as a measure of the nutritional status / cell status does not actually change. The basal metabolic rate increases minimally in the second measurement.

Overall, this result speaks for discretely higher extracellular mass fraction compared to the cell mass - e.g. by hydration - in the second measurement. Headaches occurred in only 7 participants. In all those affected, the ECM increased and the BCM decreased.

Table 2. Average values and measures of dispersion of the test subjects before (P1) and after a stay (P2) in moderate altitude.

\begin{tabular}{|c|c|c|c|c|}
\hline \multirow[b]{2}{*}{ Parameter } & \multicolumn{2}{|c|}{ Females } & \multicolumn{2}{|c|}{ Males } \\
\hline & Average/SD & Median/Range & Average / SD & Median/Range \\
\hline $\mathrm{R}-50[\Omega]-\mathrm{P} 1$ & $549.6 / 43.2$ & $551 / 157$ & $453.3 / 47.5$ & $458 / 219$ \\
\hline$R-50[\Omega]-P 2$ & $543.0 / 43.2$ & $543 / 143$ & $446.5 / 43.6$ & 447 / 202 \\
\hline Xc-50 $[\Omega]-P 1$ & $57.3 / 5.75$ & $58.0 / 23.0$ & $52.8 / 7.4$ & $53.0 / 33.0$ \\
\hline Xc-50 $[\Omega]-P 2$ & 52.4 / 6.49 & $51.0 / 26.0$ & $57.4 / 5.9$ & $57.0 / 27.0$ \\
\hline $\mathrm{R}-$ Hand $[\Omega]-\mathrm{P} 1$ & $52.5 / 56.0$ & $0.0 / 143$ & $53.9 / 60.5$ & $0.0 / 138$ \\
\hline R-Hand $[\Omega]-\mathrm{P} 2$ & 47.4 / 50.4 & $0.0 / 132$ & $54.9 / 54.3$ & 89.0 / 134 \\
\hline
\end{tabular}




\begin{tabular}{|c|c|c|c|c|}
\hline \multirow[b]{2}{*}{ Parameter } & \multicolumn{2}{|c|}{ Females } & \multicolumn{2}{|c|}{ Males } \\
\hline & Average/SD & Median/Range & Average / SD & Median/Range \\
\hline R-Foot $[\Omega]$ - P1 & $58.9 / 62.5$ & $0.0 / 165$ & $65.7 / 73.3$ & $0.0 / 189$ \\
\hline R-Foot $[\Omega]$ - P2 & $57.3 / 60.5$ & $0.0 / 135$ & $68.5 / 67.4$ & $108 / 150$ \\
\hline Testsign. $[\mathrm{x}]$ - P1 & 527.2 / 240.2 & $570 / 841$ & 422.5 / 294.7 & 334 / 935 \\
\hline Testsign. [x] - P2 & $540.1 / 234.8$ & 467 / 838 & $586.6 / 249.5$ & $603 / 759$ \\
\hline $\mathrm{FM}[\mathrm{kg}]-\mathrm{P} 1$ & $16.0 / 5.4$ & $15.2 / 26.0$ & 16.4 / 5.8 & $17.5 / 16.0$ \\
\hline $\mathrm{FM}[\mathrm{kg}]-\mathrm{P} 2$ & $15.9 / 5.5$ & $15.0 / 25.6$ & $16.6 / 5.4$ & $17.5 / 15.9$ \\
\hline FM [\%] - P1 & 18.7 / 4.2 & $19.0 / 19.3$ & $24.2 / 5.0$ & $25.7 / 15.7$ \\
\hline FM [\%] - P2 & $18.5 / 4.4$ & $19.0 / 18.8$ & $24.5 / 4.9$ & $25.7 / 15.5$ \\
\hline TBW [L] - P1 & $49.8 / 5.2$ & 49.9 / 22.2 & 36.2 / 3.8 & 37.0 / 13.1 \\
\hline TBW [L] - P2 & $50.1 / 5.0$ & $50.1 / 23.5$ & 36.4 / 4.5 & $36.6 / 11.8$ \\
\hline FFM [kg] - P1 & $68.1 / 7.1$ & $67.8 / 30.8$ & 49.5 / 5.2 & $50.6 / 17.9$ \\
\hline FFM [kg] - P2 & 68.6 / 6.8 & 68.4 / 32.0 & $49.7 / 4.7$ & 49.9 / 16.1 \\
\hline $\mathrm{ECM}[\mathrm{kg}]-\mathrm{P} 1$ & $30.8 / 4.0$ & $30.3 / 17.1$ & $23.9 / 3.0$ & $24.0 / 12.1$ \\
\hline $\mathrm{ECM}[\mathrm{kg}]-\mathrm{P} 2$ & 30.9 / 3.5 & 30.9 / 14.0 & $23.9 / 2.7$ & $23.7 / 11.1$ \\
\hline $\mathrm{BCM}[\mathrm{kg}]-\mathrm{P} 1$ & $37.3 / 3.6$ & 37.2 / 16.3 & $25.5 / 2.8$ & 24.9 / 09.1 \\
\hline $\mathrm{BCM}[\mathrm{kg}]-\mathrm{P} 2$ & $37.8 / 3.8$ & $38.0 / 18.0$ & $25.9 / 2.7$ & $25.3 / 08.9$ \\
\hline ECM/BCM - P1 & $0.836 / 0.070$ & 0.82 / 0.32 & 0.940 / 0.093 & $0.94 / 0.28$ \\
\hline $\mathrm{ECM} / \mathrm{BCM}-\mathrm{P} 2$ & $0.819 / 0.069$ & 0.82 / 0.30 & $0.925 / 0.104$ & 0.92 / 0.36 \\
\hline CM [\%] - P1 & $54.3 / 2.1$ & 54.9 / 9.8 & $51.8 / 2.5$ & $51.4 / 7.6$ \\
\hline CM [\%] - P2 & $55.1 / 2.1$ & $54.1 / 9.1$ & $52.1 / 2.8$ & $52.1 / 9.6$ \\
\hline GU [kcal] - P1 & $1793.3 / 112.1$ & $1790 / 510$ & 1422.4 / 87.1 & $1400 / 290$ \\
\hline GU [kcal] - P2 & $1809.1 / 121.2$ & 1820 / 570 & 1434.7 / 86.2 & $1420 / 280$ \\
\hline$\Phi\left[^{\circ}\right]-\mathrm{P} 1$ & $6.64 / 0.48$ & $6.6 / 2.3$ & $5.97 / 0.51$ & $5.9 / 1.6$ \\
\hline$\Phi\left[^{\circ}\right]-\mathrm{P} 2$ & $6.68 / 0.50$ & $6.6 / 2.2$ & $6.05 / 0.58$ & $6.0 / 2.0$ \\
\hline
\end{tabular}




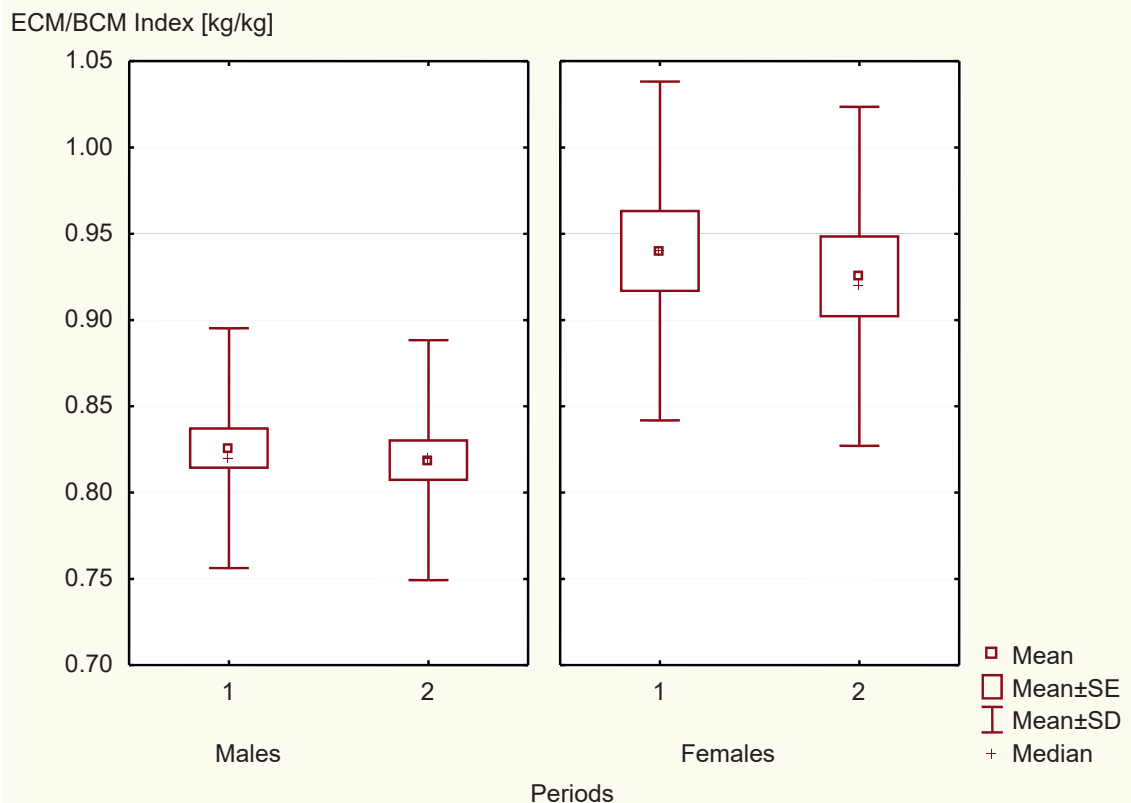

Figure 1. Box plot of the ECM / BCM index in periods 1 and 2 categorized by gender (n.s. KWT, Wilcoxon).

Resistance 50
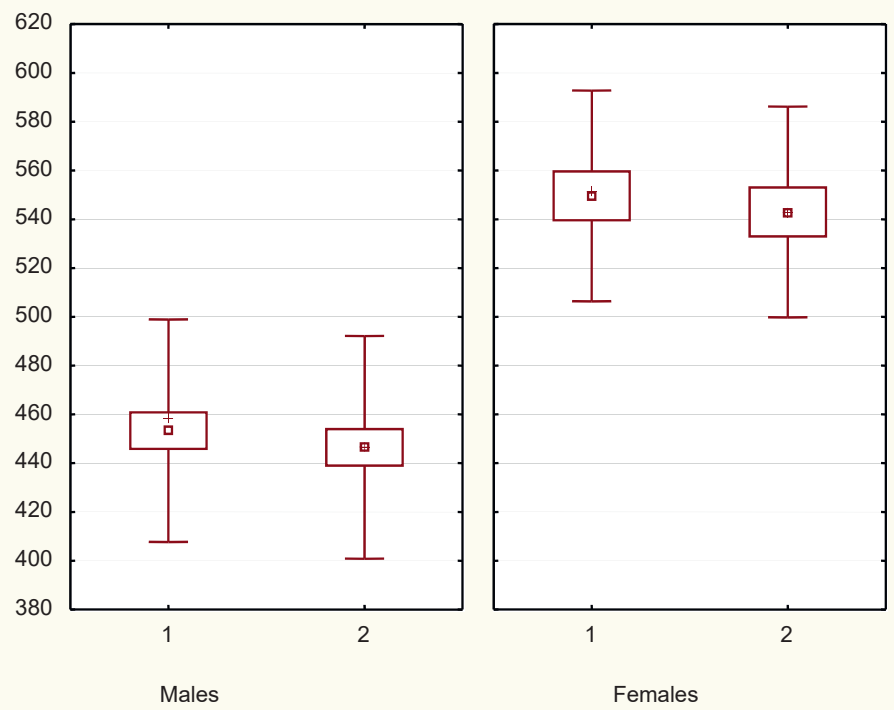

Mean

$\square$ Mean \pm SE

I Mean \pm SD

Periods

Figure 2. Box plots of effective resistance at $50 \mathrm{~Hz}$ in periods 1 and 2 categorized by gender (n.s. KWT, Wilcoxon). 


\section{DISCUSSION}

In healthy subjects, the basic parameters of active resistance, capacitive resistance or phase angle do not change significantly after a week. Although the basic value of ohmic resistance reacts in the same direction in men and women after a stay at approximately $1300-2300 \mathrm{~m}$ above sea level, the phase angle is less clear. The tendency changes indicate an increased body water (resistance), both in women and in men. Reactance and phase angle cannot be clearly interpreted, as cell integrity does not tend to change too much. The size of TBW derived from the ohmic resistance is not influenced by the stay at a moderate height.

The results are particularly important because there are only a few studies on the importance of BIA in altitude medicine. Eismann et al. [5] were able to observe increasing water retention in test subjects who developed acute mountain sickness (AMS) in high mountains between 4400 and $6100 \mathrm{~m}$ above sea level. Mountaineers who did not develop AMS, on the other hand, showed a loss of fluid. The authors see the BIA as a possible method that can be developed for early detection of AMS.

Practical recommendations must be formulated carefully. The organism tends to retain water even at a moderate height. It can be carefully concluded from this that pharmaceuticals for the treatment of headaches should not intensify this effect. Classical non-steroidal anti-inflammatory analgesics (NSAIAs or NSAIDs) seem to promote oedema formation; therefore, acetaminophen or novamine sulfone or specific therapy with triptans in migraines would be preferable $[7,9,10,26]$. The question of whether anti-inflammatory decongestant substances such as boswellic acids (frankincense), leukotrienes or bromelain can be used symptomatically is also interesting $[2,16]$. In the future, prophylactic approaches to oedema-induced complaints in the low and high mountains could also arise here.

\section{REFERENCES}

1. Beier W., Dähnert K. (1980). Seminar Physik/Biophysik - Wechselstromkreise. VEB Georg Thieme, Leipzig, 33-37

2. Böker D.-K., Winking M. (1997). Die Rolle der Boswellia-Säuren in der Therapie maligner Gliome. DÄB 1997; 94, 18: A1197-A1199

3. Castizo-Olier J., Irurtia A., Monèm J. et al. (2018). Bioelectrical impedance vector analysis (BIVA) in sports and exercise: Systematic review and future 
perspectives. PLoS One, 13(6), e0197957. https://doi.org/10.1371/journal. pone.0197957

4. Dittmar M. (2003). Reliability and variability of bioimpedance measures in normal adults: effect of age, gender, and body mass. Am J Phys Anthropol, 122, 361-370. https://doi.org/10.1002/ajpa.10301

5. Eismann C., Saile P., Schütte W. et al. (2008). Früherkennung der akuten Höhenkrankheit mit Bioimpedanzanalyse. Pneumologie, 62-P116. https://doi. org/10.1055/s-2008-1074137

6. Fiedler R., Jehle P.M., Osten B. et al. (2009). Clinical nutrition scores for prognosis of haemodialysis patients compared to lab markers and bioelectrical impedance. Nephrol Dial Transplant, 24, 3812-3817. https://doi.org/10.1093/ ndt/gfp346

7. Gillies H.C., Rogers H.J., Spector R.G., Trounce J.R. (1990). A Textbook of Clinical Pharmacology. London: Edvard Arnold, 288-338.

8. Glaser R. 1976. Einführung in die Biophysik - Die elektrische Impedanz von Zellen und Geweben 2. Auflage. Stuttgart: Gustav Fischer, 309-314.

9. Heart-safer NSAID alternatives. (2018). Harvard Health Publishing: https:// www.health.harvard.edu/heart-health/heart-safer-nsaid-alternatives. $02 / 11 / 2018$

10. Haschke M., Liechtl M.E. (2017). Metamizol: Nutzen und Risiken im Vergleich zu Paracetamol und NSAR. Schweiz Med Forum, 17, 1067-1073. https://doi. org/10.4414/smf.2017.03098

11. Herm K.-P. (2003). Methoden der Körperfettbestimmung. DZSM, 54, 153-152.

12. Jung U.M. (2018). Die bioelektrische Impedanzanalyse - Grundlagen Praxis. http://www.suessmed.com/fileadmin/user_upload/suessmed_v1/Bilder_Veranstaltungen/Juwell_Bioimpedanzanalyse.pdf. 07/10/2018.

13. Käsebieter J. 2014. Data Input GmbH - Das BIA Kompendium - IV. Ausgabe 2014. http://www.data-input.de/media/pdf-deutsch/Kompendium_III_Ausgabe_2009.pdf. 14/09/2018

14. Kaufmann S. (2015). Instrumentierung der Bioimpedanzmessung. Optimierung im Fokus auf die Elektroimpedanztomographie (EIT). Wiesbaden: Springer Fachmedien.

15. Khalil S.F., Mohktar M.S., Ibrahim F. (2014). The Theory and Fundamentals of Bioimpedance Analysis in Clinical Status Monitoring and Diagnosis of Diseases. Sensors, 14, 10895-10928. https://doi.org/10.3390/s140610895

16. Koch K. (1998). Leukotrien-Rezeptor-Antagonist: Eine neue Option für Asthma-Patienten. DÄB, 35, 22: A1391.

17. Kyle U.G., Bosaeus I., De Lorenzo A.D. et al. (2004a). Bioelectrical impedance analysis part I: review of principles and methods. Clinical Nutrition, 23, 14, 1226-1243. https://doi.org/10.1016/j.clnu.2004.06.004 
18. Kyle U.G., Bosaeus I., De Lorenzo A.D. et al. (2004b) Bioelectrical impedance analysis part II: utilization in clinical practice. Clinical Nutrition, 23, 6, 1430-1453. https://doi.org/10.1016/j.clnu.2004.09.012

19. Meschede D. (2010). Gherthsen Physik - Wechselströme. 24. Auflage. Heidelberg: Springer Verlag, 410-440.

20. N. N. (Tabellen und Richtwerte): https://klinphys.charite.de/bioinfo/2_pskripten/b4_c_tabellen.pdf. 07/10/2018

21. Piccoli A., Piazza P., Noventa D. et al. (1996). A new method for monitoring hydration at high altitude by bioimpedance analysis. Med Sci Sports Exerc, 28, 1517-1522. https://doi.org/10.1097/00005768-199612000-00012

22. Siegel S., Castellan N.J. (1988). Nonparametric Statistics for Behavioral Sciences. 2nd ed. NY: McGraw-Hill.

23. Stobäus N., Norman K., Pirlich M. (2010). Phasenwinkel und bioelektrische Impedanzvektoranalyse - Klinische Anwendbarkeit der Impedanzparameter. Aktuelle Ernährungsmed, 35, 124-130. https://doi.org/10.1055/s-0030-1248434

24. Strapazzon G., Pun M., Dal T. et al. (2017). Total Body Water Dynamics Estimated with Bioelectrical Impedance Vector Analysis and B-Type Natriuretic Peptide After Exposure to Hypobaric Hypoxia: A Field Study. High Altitude Medicine and Biology, 18, 4. https://doi.org/10.1089/ham.2017.0056

25. Tomczak J. (2003). Körperanalysen: Die bioelektrische Impedanzanalyse BIA. F.I.T. Wissenschaftsmagazin der Deutschen Sporthochschule Köln. Band 1. ALPHA Informationsgesellschaft mbH, 34-40.

26. Trayes K.P., Studdiford J.S., Pickle S., Tully A.S. (2013). Edema: Diagnosis and management. Am Fam Phys, 88, 102-110.

27. Treff G., Steinacker J.M. (2014). Monitoring des Flüssigkeitshaushalts im Sport. DZSM, 65, 342-346. https://doi.org/10.5960/dzsm.2014.155

28. Werner J. (1984). Medizinische Statistik. Eine praktische Anleitung für Studierende, Doktoranden, Ärzte und Biologen. München: Urban \& Schwarzenberg.

29. Zar J.H. (1984). Biostatististical Analysis, 2nd ed. Englewood Cliffs: Prentice Hall.

\section{Address for correspondence:}

Prof. Dr. med. Dr. rer. nat. Dr. Sportwiss. Christoph Raschka

Institute of Sports Sciences, Julius-Maximilians-University, Germany

Judenbühlweg 11

D-97082 Würzburg

E-mail: christoph.raschka@uni-wuerzburg.de 